\title{
PostsCRiPt: Originalism AND Judicial Authority
}

\author{
Jeremy Waldron* \\ New York University
}

Of course what one wants, in a volume like this, is a reply not by me but by Justice Scalia himself to the assessments and criticisms offered in these six essays. Sadly, that is impossible, and I shall not attempt in my comments here to channel Antonin Scalia or to say what I think he would or should have said.

Nor can I respond to everything in the essays presented here. They pursue a variety of themes in a variety of ways, some focusing on the distinctive features of Scalia's own approach to adjudication, some focusing on patterns of judicial decision-making in which he has participated substantially, but often as one justice among others. Jane Marriott's discussion of campaign finance is an example here; as she notes, Scalia has "rarely authored a majority campaign finance opinion for the Court." Some are assessments of patterns of dissent (for example, Ian Loveland's discussion of the sexual orientation cases) rather than Scalia's participation in the actual crafting of Court decisions (James Pfander's essay on the law of standing is an example).

Brian Jones and Austin Sarat are convinced that Justice Scalia became, in the eyes of many people, a "sacred symbol" in the higher judiciary-one of a long and romantic line of "brilliant and elegant philosopher judge[s]" that include Sir Edward Cook, Oliver Wendell Holmes and Louis Brandeis. ${ }^{2}$ There was a sense that his death posed a particular crisis for conservatives, not just because it might change the balance on the Court but because it meant the loss of an icon of judicial conservatism, one whose presence had had a transformative impact on American adjudication.

I am not sure I would use the term "sacred symbol," even on the definition given at the end of this essay. ${ }^{3}$ Its use by Jones and Sarat is a little confusing since they associate it with the fact that Justice Scalia revealed and humanized his personality as a judge rather than making himself into a mere mouthpiece of a particular jurisprudence. ${ }^{4}$ If there was something sacred in his jurisprudence, it was his readiness to desacralize the pieties of his colleagues. If he was an icon, it was in the midst of his iconoclasm. He wrote clearly, straightforwardly, and unequivocally about what seemed to him to be at stake both in particular cases but also and above all in the theory and ethos of interpretation. Also, as Jim Allan emphasizes, ${ }^{5}$ Justice Scalia made himself more than usually available for

\footnotetext{
University Professor, School of Law, New York University.

1 Jane Marriott, Tenured Fox in the Democratic Henhouse?, 6 BR. J. Am. Leg. Studies 41 (2017).

2 Brian Christopher Jones and Austin Sarat, Justices as "Sacred Symbols": Antonin Scalia and the Cultural Life of the Law, 6 BR. J. Am. Leg. Studies 7 (2017).

$3 \quad$ Id. at 23.

$4 \quad I d$. at $16-18$.

5 James Allan, One of My Favorite Judges: Constitutional Interpretation, Democracy and Antonin Scalia, 6 BR. J. Aм. Leg. Studies 25, 29-31 (2017).
} 
lectures and debates outside the courtroom. His interventions - some subsequently published, many just remembered in anecdotes like Allan's - lent substance and richness to jurisprudential views that necessarily required abbreviation in the context of judicial opinions.

Many of these essays reflect on Justice Scalia's originalism - his view that modern judges should approach constitutional interpretation by looking for something called the original understanding of the language used in the text of the Constitution. We should understand "cruel and unusual" as it was understood in 1791 and "equal protection of the laws" as that phrase was understood in 1868.

I will come back to this issue of textual understanding in a moment. But actually, it is one of the virtues of these essays that they also consider dimensions of originalism that go beyond textual interpretation. For example, James Pfander's thoughtful essay on Scalia's contributions to the law of standing emphasizes not just the original understanding of the text of Article III of the Constitution-words like "Cases" and "Controversies" - but also to the original understanding of the practices that the Article implicitly refers to. ${ }^{6}$ I mean things like the practices of the Common Law at the time of the framing of the Constitution, which will help us understand what the Constitution's immediate audience understood when they heard a phrase like "judicial power."

Here is another example. Richard Epstein is adamant that an originalist should pay attention to structural features of the Constitution - that is, to the way in which the Takings Clauses, for example, in the Fifth and Fourteenth Amendments were understood to fit together into a general charter regulating the powers of government with regard to private property. ${ }^{7}$ Original understanding of text is not the beginning and end of originalism. In addition, originalism comprises original understanding of constitutional structure and the relation of text to constitutional principles that were taken for granted by those who drafted the constitution. And Epstein makes a good case that Justice Scalia's contributions to the Court's takings jurisprudence sometimes fell short of these dimensions of originalist understanding. Scalia is usually denounced for being too conservative, but Professor Epstein criticizes him for not going far enough in the protection of private property from state regulation. In this connection, Epstein makes the important point that "there is no necessary, or even implied, connection between originalism and judicial restraint." ${ }^{\text {" }}$ Originalism is sometimes seen as a strategy for judicial restraint, but whether it restrains judges or empowers them ought to depend on what the original understanding of judicial authority was, as well as on the original understanding of the terms of the Constitution that judges are supposed to apply. If the text of the Constitution speaks "in sweeping terms," then that implies that judges have sweeping powers, and to try to limit that power one would have to be an anti-originalist, acting on one's personal preference for deprecating judicial authority. Epstein worries that Scalia pulled back from the radical implications of his (Epstein's) conception of the takings restriction on grounds of judicial restraint. And although in other areas, Scalia adverted to underlying constitutional structures and principles (like separation of powers),

6 James Pfander, Scalia's Legacy: Originalism and Change in the Law of Standing, 6 Br. J. Am. Leg. Studies 85 (2017).

7 Richard Epstein, Missed Opportunities, Good Intentions: The Takings Decisions of Justice Antonin Scalia, 6 BR. J. Am. Leg. Studies 109 (2017).

$8 \quad I d$. at 113 (emphasis in the original). 
Epstein believes Scalia is open to criticism for not having followed through on the original understanding that "broad and ambiguous constitutional provisions should be read consonant with their general sweep and implications." "Whatever one thinks of Epstein's particular argument about property, this is a powerful and important philosophical point about the understanding of originalism.

James Allan is critical of Justice Scalia's' originalism in a way that takes us back to the issue of textual understanding. Scalia's originalism he says, is "new originalism" and Professor Allan favors an older version. ${ }^{10}$ The older originalism interprets text according to the meaning intended by its authors, whereas the new originalism interprets text according to the way in which contemporary audiencescontemporary with its original promulgation - would have understood it. Authors' intention or audience's understanding? - that is the question. Allan claims that if we stick with original understanding, as Scalia did, then we face the problem of constructing an idealized version of the eighteenth century audience whose understanding this version of originalism is supposed to privilege. He implies that the older originalism faces no such difficulty, presumably because many fewer people were involved in authoring the Constitution than in understanding it. But that won't do at all. The authors of the Constitution are not its framers (who were relatively few), but those by whose authority it came into force. These are the thousands of citizens who ratified it in the thirteen states in 1787-1791 and/ or the many other states involved in the ratification of the Fourteenth Amendment a hundred years later. Either way we face the difficulty of constructing a public meaning out of a great many individual understandings. In fact, it is arguable that the scale of the problem is more or less the same on both sides. In the case of a constitution whose authority derives from popular ratification, its authorship - the number of its authors - is roughly the same order of magnitude as its addressees. That's the point about popular sovereignty.

The other difficulty I have with Allan's account is that he says nothing about the distinction between the two brands of originalism so far as interpreting legislation is concerned. Justice Scalia felt very strongly about this and furiously resisted the notion that statutes should be interpreted in the light of historic legislative intent, particularly to the extent that such intent was supposed to be disclosed otherwise than through the statutory text. ${ }^{11}$ There are powerful reasons for textualism, as opposed to intentionalism, in the case of statutes, and those carry over into the constitutional context. Scalia's textualism is really the nerve of his originalismJane Marriott makes this clear at the end of her paper ${ }^{12}$ - and it is unfortunate that Professor Allan fails to understand this point.

Much of Allan's enthusiasm for the jurisprudence of Justice Scalia has to do with the latter's support for democracy and his suspicion of any practice of judicial review that goes beyond the settled terms of the constraints laid down in the Constitution (as originally intended or as originally understood). I wish Professor Allan had had the opportunity to address Professor Epstein's insistence (mentioned earlier) that originalism is not necessarily a doctrine of judicial restraint. Whether

Id. at 113 .

Allan, supra note 5, at 33.

See Antonin Scalia, A Matter of Interpretation: Federal Courts and the Law (Amy Gutmann ed., 1997).

12 Marriott, supra note 1. 
it is or not depends on what the terms of the constitution and particularly the Bill of Rights actually are. If the constitutional constraints as laid down in 1787, 1791, and 1868 are modest and rule-like (like the norm, that the President must have attained the age of thirty-five years), that is one thing. But if they use value-terms like "cruel" or "unreasonable" or potentially sweeping terms like "equal protection of the laws," that is something quite different. Those who authored and ratified such terms must have known that they require those who interpret them to make evaluative judgments in their own voice, and that such judgments may differ from age to age. The eighteenth and nineteenth century authors were well-educated men, who knew that what one age regarded as cruel, for example, might not have been regarded as cruel, by an earlier generation. We must assume that they decided to use the term "cruel" in full recognition of this possibility, not in denial of it, nor in the hope that people would read it as something other than a value-term (perhaps as an historical record of an earlier generation's evaluations). Of course this makes it difficult to sustain Allan's equation between originalism and judicial restraint. But as Epstein points out, if we are originalists we have to follow original understandings where they lead us, and not just in the direction given by our own — his and mypolitical antipathy to judicial review.

As I say, Allan and I share an antipathy to strong judicial review, arguing strenuously against its introduction in legal systems that do not have it (like New Zealand, for example, and the United Kingdom). But we must not project that antipathy onto Justice Scalia. He was sworn to uphold the Constitution of the United States and without any doubt that required him to strike down state and federal laws that the Constitution condemned as well as upholding those that it did not. I know from talking to him that Scalia understood both sides of this equation. $\mathrm{He}$ understood (a) why there were such things as constitutional constraints; he also understood (b) what was lost when a democratically-enacted piece of legislation was struck down. On both sides, he thought an originalist understanding of the Constitution was called for. But I think it would be a mistake to cite (b), by itself, as a ground for an overly restrictive originalism. Whether constitutional constraints should be read narrowly or broadly depends, for an originalist, on nothing but the way in which they were originally understood. And that is always an open historical question.

Some of these issues come to a head in Ian Loveland's essay. Professor Loveland is concerned with the rearguard battles that Scalia fought against the striking down of laws penalizing homosexual activity or disempowering people on account of their sexual orientation. Loveland rightly draws attention to the illtempered tone of some of Justice Scalia's interventions, particularly in dissent. One of his dissents (in Obergefell v. Hodges) Loveland calls "a petulant diatribe."13 Another (Scalia's dissent in Lawrence v. Texas) is described as: "a splenetic rant more suited to a locker room than a court." 14 Evidently Loveland does not rejoice, as James Allan does, in the "scathing" and "combative" quality of Scalia's speech and writing. ${ }^{15}$ Overall, Professor Loveland does not have a high opinion of Scalia's ability as a judge. He acknowledges that opinions may differ on Justice Scalia's rather narrow reading of the Constitution. Maybe, says Loveland, "one can find

\footnotetext{
Ian Loveland, The Sexual Orientation Cases, 6 BR. J. Am. Leg. Studies 59 (2017). Id. at 73 .

Allan, supra note 5, at 29, 30.
} 
sound doctrinal (or if one prefers constitutional) reasons to support the substantive conclusions that [Justice Scalia] defended in these cases." 16 But he thinks Scalia sometimes fell short of standards of honesty. ${ }^{17}$ And he submits that whatever good reputation Scalia has, even after his death, is quite unsustainable. ${ }^{18}$

I believe, however, that in three instances Loveland's criticisms of Justice Scalia miss the mark. First, he says that, in his dissenting opinion in Romer $v$. Evans, Scalia “equate[s] a person's consensual sexual activities with committing murder." 19 Loveland says that this equation "is better described as unhinged than unsound." ${ }^{20}$ In fact Justice Scalia made no such equation. At most, he said that it was not inappropriate for citizens of Colorado to disapprove of homosexual conduct any more than it was inappropriate for them to disapprove against other acts they regarded as reprehensible, like murder. This is an analogy, not an equation. Like all analogies, it draws attention to just one similarity between two activities without in any way claiming that the analogue and the activity analogized to it are identical in other respects. In the passage that Professor Loveland is concerned about, the only similarity adverted to is that some citizens of Colorado may find both forms of conduct reprehensible. Scalia points to this similarity just in order to refute the general proposition that it is always constitutionally inappropriate for voters or legislators to exercise their powers on the basis of what they judge reprehensible.

Secondly, Loveland claims that Scalia demonized the petitioners-those seeking to overturn state anti-sodomy laws-in his dissent in Lawrence v. Texas. But all Loveland can cite as evidence for this is Scalia's saying that the petitioners "engaged in a seventeen year crusade" to have Bowers v. Hardwick overturned. ${ }^{21}$ Is "crusade" a demonizing word? Maybe when Al Qaeda talked about coalition armies in Iraq and elsewhere as crusaders, it was a way of demonizing the West. But I don't think anyone would put that interpretation on Scalia's use of the term. Loveland is evidently sensitive to this point, by the way, since he feels he has to add a footnote saying "The use of 'crusades' presumably being intended to denote ideological extremism." 22

Thirdly, in his comments on the Obergefell decision, Professor Loveland says that Scalia's dissent is weakened by the way in which he "continually misrepresents the nature of 'the People'."23 Scalia complained that the Court's decision in Obergefell took away from the people the right to define marriage as they please. As Loveland observes, he seems to have been referring to the people of the various states: the right of the people of Michigan to define marriage as they please, the right of the people of Ohio to define marriage as they please, and so on. Loveland thinks this is a mistake - he calls it "substantive nonsense"24 - because by focusing on these "mini-Peoples" (Loveland's phrase), Scalia ignores the fact that the people of the United States retain the right to overturn Obergefell through the medium of

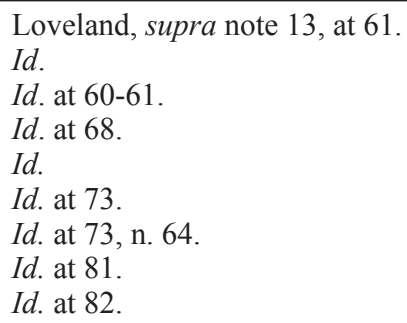


an Article V amendment to the Constitution if they want to. I don't know whether Justice Scalia regarded this right of the people of the United States as important or unimportant in this context. (Loveland himself says that it is "very unlikely" that majority support for such an amendment will ever emerge among the American people as a whole. By the way, the implication that all it would take is a majority of "the People" is another mistake in Loveland's analysis: the terms of Article V are strenuously super-majoritarian.) But the reason why Scalia focused on the peoples of the respective States is that, in the American federal system, family law (including the rules for marriage) is a matter for the States not the federal government. So, at least in the first instance, the effect of Obergefell is to deprive state legislators and those who vote for them of the right to control marriage law through democratic enactments. That is the "threat to American democracy" that Scalia is referring to and that is the democratic process which - as Loveland generously notes ${ }^{25}$-Scalia said was working "at its best" before Obergefell was decided.

Jane Marriott is also interested in Scalia's views on democracy, though in a different context. Her essay is about campaign finance laws, and the reasons Scalia gives for striking down such laws as unconstitutional. Both in the campaign finance cases and (as we have seen) in other contexts too, Scalia shows great faith in democratic decision-making. He has, says Professor Marriott, "a healthy regard for the abilities of citizens to make informed choices without government interference, ${ }^{, 26}$ and he wants to protect the exercise of that capacity from regulations that might threaten it. But campaign finance regulation is itself a product of that democratic capacity; so surely such regulations should also command respect as an instance of the very self-government that Scalia says he favors.

Marriott argues that there is a sort of definitional dilemma here that Scalia never properly confronts - definitional with regard to "democracy." 27 I wonder whether it really is all that much of a dilemma. No one thinks that the integrity of the democratic process is naturally or magically secure nor that it is invulnerable to attack by the very majorities it empowers. By and large, majority decisionmaking in a legislature might be a healthy and legitimate mode of decision, but there are things that can be done or permitted that will undermine that. Defenders of campaign finance restrictions believe that allowing money-perhaps particularly corporate money - to affect democratic politics will yield a less respectable politics. Opponents say that limiting the influence of money - which is perhaps a way of limiting speech-affects the conditions on which sound democratic decisionmaking is predicated. This is a genuine disagreement. Like Professor Allan, we may favor its being resolved - like all disagreements - through majority-voting in the legislature. ${ }^{28}$ But as I said in my comments on Allan's piece, Scalia, as a sworn justice in the American system, did not have the luxury of considering that issue in the abstract. He had to consider it in the light of the First Amendment's protection of free speech, which he was sworn to uphold. He had no choice therefore but to separate the two questions: (1) Is a given range of campaign contributions protected by the First Amendment's commitment to free speech? and (2) Do the campaign contributions in question make it more likely or less likely that democracy will

\footnotetext{
Id. at 80 .

Marriott, supra note 1, at 44, 54 .

Id. at 54-56.

Allan, supra note 5, at 38-39.
} 
work as it is supposed to work? We can argue endlessly, if we like, about the interpretation of "freedom of speech" in the First Amendment. But question (1) is not the same as question (2), and unless we run them together we are not really caught on the horns of Marriott's dilemma. 